\title{
Health and the Community
}

$\mathrm{O}^{\mathrm{N}}$ September 2, the physiologists of the British Association for the nonce forsook their frogs, eavies, rabbits and almost, but not quite, their rats. They left the cloistered calm of controlled experiments in camera and the discussion of intricate problems of nerve conduction or surface films, interesting, no doubt, to those who have at least mastered the terminology but deadly dull to those who have not, and descended to the world of men, and to a consideration of the criteria of the healthy life both of man as an individual and as an integer in a community. They could not, however, quite part with the rat. The important part this rodent has played and is still playing in the progress of civilization would need a whole article to describe, but we only heard of its value in assaying food for certain vitamins, and were warned of the dangers of accepting results obtained from experiments on rats as applicable without reserve to man. For example, the anti-vitamin D influence of cerealsso clearly demonstrable on rats and puppies, due to the absence from their alimentary tracts of an enzyme capable of freeing phosphate from phytin leads to low-phosphorus rickets, a condition unknown in man. The breakfast cereal, whether provided dry or as Scots porridge, thus leaves the physiological court of appeal without a stain on its character, or, to be more cautious, with the Scots verdict "not proven".

Experiments on animals have given valuable information, and they are still necessary, especially for purposes of assay, but before far-reaching conclusions of value to the community can be drawn, they must be shown to be valid for man by long-term experiments on man. Before these can be attempted, some measure of agreement must be reached as to standards of performance. What is a healthy man? How can his health be measured? It is all very well to talk of the bloom of health, the clear eyes, silky sheen of hair, easy upright carriage and the pleasant facial expression of those physiologically fit, but these qualities are immeasurable. They have no yard-stick. As standards are necessary, such items capable of measurement as height-weight ratio, chest expansion and absence of demonstrable fatigue after moderate work have to be used for want of better. A person may be called normal if he does not depart more than \pm 5 per cent from the average.

This led to a discussion on sub-nutrition-a vague lack of efficiency demonstrably due to inadequate intake of the so-called protective foods.
The threshold for these foods varies from individual to individual, some requiring more and some less to enable vital processes to be carried on at full efficiency ; so, to play for safety in planning diets for large groups, maximum amounts should be given (not necessarily taken). Laboratory animals have been shown to suffer from excess of these foods. In fact, many diseases common to man may have symptoms similar to those produced by overfeeding rats with certain dietary constituents, but the overfeeding has to be gross. So far, no ill effects have followed luxus consumption by a healthy man of any article of diet taken in the ordinary course.

Health and industrial efficiency are not quite synonymous terms, but there is no doubt that ill health causes large industrial losses. The Section had, as guest speaker, Dr. E. Atzler of Dortmund, who told, in fluent English, of his attempts, which met with a large measure of success, to raise the industrial efficiency of the workers in Westphalia. $\mathrm{He}$ stressed the value of slow adaptation to working conditions. The operative starting work under new conditions has to become acclimatized, and unless this is done carefully his efficiency and his general health may be impaired. He directed special attention to mineral metabolism-the need for phosphates being noticeable in those about to undergo heavy muscular work, and for chlorides when the work was to be done under semitropical conditions. These mineral needs are less after the worker has become 'hardened' to his job.

The Section turned its attention to more general problems. It was told of a steadily decreasing birth-rate, especially in those classes more financially comfortable. It has been computed that for every hundred women aged twenty-five years in England and Wales to-day, there would be only 83 in 1942, 70 in 1952 and 60 in 1962 . Whatever we do now, these figures cannot be increased. Further, there is a tendency to postpone marriage in the better-off classes. Thirty-six per cent of the women of the professional classes who marry do not arrive at the altar until they have passed thirty years of age. The corresponding figure for miners is 10 per cent (Reg. Gen. Report for England and Wales, 1921). Even those who marry younger tend to postpone childbirth. To determine the safest age for reproduction, that is, the age with the lowest death-rate for mother and child, necessitates the close study of a large area with a fairly stable population. Figures were given of 30,000 mothers, 98 per cent of whom came from 
the classes covered by State insurance. It was made clear that the safest rate of reproduction for both mother and offspring was the modal rate, that is, when the first pregnancy occurred when the mother was round about twenty-five years of age, the second, third and fourth between the ages of twenty-five and thirty and not more than three pregnancies in the next five years. On the whole, this rate was observed only by the lower paid members of the community. As income (or security of tenure) improves, there is a tendency to postpone the first pregnancy, with obviously a shortening of the reproductive period and, statistics showed, with a consequent increase both in maternal mortality and in the number of stillbirths. The increase in still-births is almost offset by the decrease in child mortality. The result of this is that those who are least able to obtain the necessary food for full health are the very people who are contributing most to the maintenance of the population. To improve the condition of the child-bearers and incidentally of the children born, education in food values and other physiological truths is not of much use unless the necessary food and service are available at a price to suit their incomes and conditions of life.

D. B.

\section{Obituary Notices}

\section{Mr. A. Sharples}

$\mathrm{M}^{\mathrm{r}}$ R. ARNOLD SHARPLES, formerly mycologist in the Department of Agriculture, Federated Malay States and head of the Pathological Division of the Rubber Research Institute of Malaya, died at St. Anne's-on-Sea on August 6, after a long illness.

Mr. Sharples was born at Great Harwood, Lancashire, on November 25, 1887. He received his elementary education at Stoneyholm School, Burnley. He left school early, but later, overcoming great difficulties, he became a student at the Burnley Technical College, where in 1908 he won a scholarship to the Royal College of Science, London, and at the same time was awarded King's prizes in both geology and mineralogy. At the Royal College of Science he was especially interested in botany and came under the notice of Sir John Farmer as a particularly promising student. $\mathrm{He}$ became an associate of the Royal College of Science and was awarded the diploma of the Imperial College of Science in 1912. His interest in mycology had already been stimulated by his association with north-country naturalists, especially the late $\mathrm{Mr}$. James Needham of Hebden Bridge. On leaving the Royal College of Science he was appointed assistant mycologist in the Department of Agriculture, Federated Malay States, but before going to the East he spent some time at Kew to extend his knowledge of mycology under the direction of the late Mr. G. Massee and Miss Wakefield. All his professional life was spent in Malaya. In 1916 he was appointed chief mycologist in the Department of Agriculture, and in 1930 he was seconded from Government service to be head of the Pathological Division of the Rubber Research Institute of Malaya, situated at Kuala Lumpur. He retired in 1934 and settled at St. Anne's-on-Sea.

During the Great War he served in Mesopotamia (1917-19) as a lieutenant in the Royal Engineers. In this capacity he was concerned with the purification of water supplies for the troops.
From the time of his arrival in Malaya until his retirement, Sharples was a most energetic and able investigator of the diseases of tropical crops, especially rubber. From 1914 onwards there was a constant stream of papers from his pen, published by the Department of Agriculture or the Rubber Research Institute, or appearing at home in the Annals of Botany and the Annals of Applied Biology. At one time or another he covered the whole range of rubber tree pathology. He treated exhaustively, sometimes in association with colleagues, such diverse topics as the spotting of plantation rubber by mould fungi, pink disease, the root and branch disease of rubber trees caused by Ustulina zonata, mouldy rot and brown bast of the tapped bark, lightning damage to coco-nut and rubber trees, and callus formation in tropical plants. These and other investigations were marked by thoroughness and insight. Sharples was not content merely to investigate a disease sufficiently to give advice to planters, but being interested in the fundamental aspects of plant pathology, he examined in great detail the relations of plant and parasite or other disease-producing agency in connexion with environmental conditions. His account (with H. Gunnery) of callus formation in Hibiscus and the rubber tree (Annals of Botany, 1933) is probably the best description available of the development of this tissue. His wide botanical interests prevented him from becoming a narrow specialist. Sharples was an example of the best type of officer in the tropical departments of agriculture, who realizes both the practical and the fundamental issues involved in problems of crop cultivation.

Sharples had a profound knowledge of all matters concerning rubber cultivation in Malaya, and his advice was constantly sought by the planters, with whom he was always on the best of terms. They had complete confidence in him. $\mathrm{He}$ will long be remembered with gratitude by the planting community of Malaya. During his service with the Rubber Research Institute he acted as director for a period. 